\title{
Feministisiä
}

\section{luentoja naiseuden}

ja väkivallan

\section{representaatioista}

\section{Sanna Karkulehto ja Leena-Maija Rossi (toim.): Sukupuolija väkivalta: Lukemisen etiikkaa ja poetiikkaa. Helsinki: SKS, 2017, 329 S.}

Hyvä artikkelikokoelma antaa kuvaavia, tutkimuskohteensa kannalta relevantteja ja yleistettäviä esimerkkejä aihepiiristään. Juuri tässä Sanna Karkulehdon ja Leena-Maija Rossin sukupuolen ja väkivallan representaatioita TV-sarjoissa, elokuvissa ja kirjallisuudessa käsittelevä kokoelma onnistuu mainiosti. Kokoelma on napakka, feministisestä näkökulmasta laadittu kotimaisen kulttuurin- ja kirjallisuudentutkimuksen alan päivitys yksien kansien välissä. Teos on suomenkielinen, mikä on kunnioitettava tiedepoliittinen kannanotto nykyisessä englanninkielistä julkaisemista painottavassa yliopistomaailmassa. Sama pätee kotimaisten tutkijakollegoiden työn esiin nostamiseen monissa kokoelman artikkeleissa. Lisäksi kokoelma on verkossa vapaasti saatavilla.

Kirjoittajat ovat kahta lukuun ottamatta kotimaisia kulttuurin, kirjallisuuden ja sukupuolen tutkijoita. Artikkelit analysoivat sukupuolen, vihan ja väkivallan kytköksiä pääasiassa oman aikamme suomalaisissa ja kansainvälisissä elokuvissa, televisiosarjoissa, proosakirjallisuudessa, runoudessa, nettikeskusteluissa ja valokuvamateriaalissa. Otsikko tarkentuu johdannossa väitteeseen, jonka mukaan teksteissä, joissa käsitellään miesten ja naisten suhteita, naisen ruumis on edelleen - kulttuurin, mediamaailman ja väkivallan representaatioiden muutoksista huolimatta - useimmiten hyväksikäytön kohde. Näin ollen kokoelman painopiste onkin naisten kokemassa väkivallassa; miehiin kohdistuva väkivalta jää vähemmälle käsittelylle. Artikkelit nostavat esiin erityisesti naissukupuolta ja valtaa kriittisesti käsitteleviä tutkimuskysymyksiä, tapoja kyseenalaistaa sukupuoleen liittyvää väkivaltaa sekä hahmotella vaihtoehtoisia tapoja lukea väkivallan tekstejä. Näitä tapoja toimittajat kutsuvat lukemisen etiikaksi ja politiikaksi. Kokoelman kohdeyleisöksi valikoituu todennäköisesti ensisijaisesti feministisesti orientoituneita kulttuurin- ja kirjallisuudentutkijoita, mutta myös ylipäätään sukupuolen ja väkivallan yhteiskunnallisista ja kulttuurisista rakentumistavoista kiinnostuneelle lukijalle kokoelma antaa pohdittavaa.

Kokoelma jakautuu kolmeen osaan, jotka nivoutuvat teorian tasolla yhteen, joskin viimeisen osan artikkelien aineistovalinnat poikkeavat edellisistä. Ensim- 
mäisen osan neljä artikkelia tarkastelevat toisaalta elokuvien ja televisiosarjojen tapoja uusintaa, luvallistaa, liikuttaa ja naiseuttaa väkivaltaa, mutta tarjoavat samalla myös uudenlaisia merkityksiä ja mahdollisuuksia toisin toistamisen analyysiin. Yhdysvaltalaisen aineiston vahva osuus tässä osassa on ymmärrettävää sen hegemonisen aseman vuoksi - huolimatta kotimaisen elokuvan suosion kasvusta viime vuosina. Anna Pitkämäki analysoi uhriutta ja haavoittuvuutta kahdeksassa 2000-luvun kotimaisessa elokuvassa. Hän korostaa kiinnostavalla tavalla sitä, miten pohjoismaisen vahvan naisen trooppi toimii esteenä väkivallan uhrin haavoittuvuuden ja heikkouden kuvaamiselle. Tämä liittyy suoraan naisten kokeman väkivallan vähättelyyn: kun väkivallan seurauksista ei jää näkyviä jälkiä, sen olemassaolo voidaan kieltää. Myös Leena-Maija Rossin komediallista väkivaltaa Suomessakin suosituissa amerikkalaisissa elokuvissa ja televisiosarjoissa käsittelevä artikkeli analysoi väkivallan seurausten häivyttämistä luvallistamisen ja luonnollistamisen avulla. Keskeinen kysymys siitä, onko väkivalta aina osa komedian kuvastoa, jää lukijan mieleen ja synnyttää Rossin kaipaamaa kriittistä suhtautumista "hauskana" esitetyn väkivallan ongelmiin. Aino-Kaisa Koistinen pohtii affektiteorian avulla koneen ja ihmisen eroja väkivaltaisissa kohtaamisissa amerikkalaisessa ja ruotsalaisessa tieteissarjassa. Koistinen toteaa, että kumpikin sarja esittää sekä ihmiset että eiihmiset affektin kohteina, jolloin raja ihmisen ja Toisen välillä hämärtyy. Tämä puolestaan mahdollistaa ihmisyyden käsitteen kyseenalaistamisen erilaisten elämänmuotojen eettisissä kohtaamisissa. Heidi Kososen artikkeli käsittelee naisten itsemurhien kuvausta tuoreessa amerikkalaisessa kauhuelokuvassa historiallisesta näkökulmasta. Hänen päätelmänsä itsemurhakuvastoista, joissa toistuva marginalisointi ja feminisointi tuottavat stigmaa ja merkitsevät itsemurhan "pahaksi kuolemaksi", on kiinnostava.

Toisen osan neljä artikkelia analysoivat väkivallan representaatioita kotimaisessa proosakirjallisuudessa ja runoudessa. Myry Voipio tutkii rinnakkain sekä suomen- että ruotsinkielistä kotimaista tyttökirjallisuutta, vaikka toisella kotimaisella julkaistua kirjallisuutta olisi voinut olla mukana enemmänkin. Pitkämäen tavoin Voipio nostaa esiin tyttöihin kohdistuvan vahvuuden eetoksen. Kirjoissa tytöt ovat selviytyjiä, jotka eivät kuitenkaan jää yksin kokemustensa kanssa, vaan heidän itsenäisyytensä rakentuu kollektiivisesti. Hanna Stormin kahta syömishäiriöromaania tarkasteleva artikkeli paneutuu anorektisten naisruumiiden kontrollointiin ja siihen liittyvään reproduktion pakkoon. Stormin analyysi osoittaa, miten romaanien päähenkilöiden elämä ja pyrkimykset ovat monin tavoin alisteisia reproduktion vaatimukselle. Satu Koho hyödyntää Riikka Pulkkisen romaanin Raja (2006) tulkinnassa kontekstuaalista lukutapaa ja feministisesti orientoitunutta kulttuurimaantieteen teoriaa analysoidessaan sosiaalisesti määrittyneiden rajojen dialektiikkaa. Hän lukee romaania tekstinä, joka nostaa esiin erilaisia rajoja - mukaan lukien puhuttelevan ajatuksen hiljaisuudesta, joka merkitsee sen, mitä jää piiloon rajan taakse. Minna Halosen ja Sanna Karkulehdon yhteisartikkeli on kokoelman 
ainoa lyriikkaa käsittelevä teksti. Analyysissaan he pureutuvat naisruumiisiin kohdistuvaan kontrolliin Saila Susiluodon tuotannossa intertekstuaalisuuden näkökulmasta. Artikkelissaan Halonen ja Karkulehto tarkastelevat sitä, miten Susiluodon perinteisiä myyttejä ja satuja hyödyntävät tekstit uudistavat kulttuurissa luonnollistuneita merkityksiä ja vaativat samalla lukijaa samaistumaan niitä vastustavaan positioon.

Kolmas osa jää hieman irralliseksi, ja olisikin ollut lukijan kannalta mielenkiintoisempaa, jos se olisi kokonaisuudessaan keskittynyt oman aikamme digitaaliseen kulttuuriin, kuten Tuija Saresma kiinnostavassa nettipropagandaa käsittelevässä artikkelissaan. Naisiin kohdistuvan väkivallan näkökulmasta Andrea Petôn kirjoittama ja Markku Nivalaisen sujuvasti suomentama teksti, jossa tarkastellaan Unkarissa sotilaiden toisen maailmansodan aikana tekemiä raiskauksia ja niitä näihin päiviin asti varjostanutta hiljaisuuden kulttuuria, nivoutuu hyvin kirjan aihepiiriin ja teoreettisiin lähtökohtiin. Kontekstuaalisesti artikkelin aihe on kuitenkin kaukana suomalaisille tutusta kulttuuripiiristä, johon muut tekstit sijoittuvat. Rosemary Hennessyn eri luentatapoja ja niiden suhdetta affektiin käsittelevä luku (suom. Rossi ja Karkulehto) toimii metodologisena tiivistelmänä, joskin sijoitettuna kokoelman alkuun se olisi täydentänyt johdannon määrittelyjä.

Kaiken kaikkiaan naisruumis näyttäytyy kokoelmassa kovin yhtenäisenä. Se on väkivallan kohde, uusintava äitiruumis, kauneusihanteita toteuttava, seksuaalistettu objekti, muokattava materiaali. Tässä kohdassa nousee esiin kokoelman korostama kysymys luentojen tärkeydestä: millaisia vastustavia luentoja on mahdollista tehdä, ja mikä on luentojen poliittinen merkitys sukupuolen ja väkivallan kulttuurisessa ja yhteiskunnallisessa tuottamisessa?

\section{Helen Mäntymäki}

